Zagazig J. Agric. Res., Vol. 43 No. (3) 2016

http:/www.journals.zu.edu.eg/journalDisplay.aspx?Journalld=1\&queryType=Master

\title{
CHEMICAL FEATURES OF SOME SOIL RESOURCES IN EL-TINA PLAIN OF NORTHWESTERN SINAI, EGYPT
}

\author{
Sahar A.S.E. Shahin ${ }^{1 *}$, Salah A. Tahoun ${ }^{2}$, Tharwat K. Ghabour ${ }^{1}$, El-Sayed A. El-Naka ${ }^{2}$ \\ 1. Soils and Water Use Dept., Nat. Res. Cent., Dokki, Cairo, Egypt \\ 2. Soil Sci. Dept., Fac. Agric., Zagazig Univ., Egypt
}

\begin{abstract}
El-Tina plain comprises an expansive landscape of soils that are collectively covered by the mega soil reclamation project of El-Salam/Sheikh Gaber Canal. The objective of this work is to prepare a database for some localities in the area, a prerequisite to allocative efficiency nexus for sustainable development in Egypt. A reconnaissance survey led to choosing 16 sites, each was completely described in the field and sampled for subsequent analysis. Field inspection revealed that the soils are barren with shallow watertable. Soil genesis indicates that they are derived from the defunct Pelusiac Branch of the Nile that used to run across northwestern Sinai. Particle size analysis revealed that some soils contain up to $80 \%$ clay. Chemical analysis revealed that most soils are heavily infested with salinity and sodicity, aside from other constraints including salt crusts. Due to salinity perturbation, exchangeable sodium percentage (ESP) is not correlated with sodium adsorption ratio (SAR). The dominant soluble cation is $\mathrm{Na}^{+}$at $1323.34 \mathrm{cmole}^{-1}$ followed in sequence by $\mathrm{Mg}^{2+}$ at $867.59 \mathrm{cmole}^{-1}$, $\mathrm{Ca}^{2+}$ at $386.44 \mathrm{cmole}^{-1}$, and $\mathrm{K}$ at $57.85 \mathrm{cmole}^{-1}$. The dominant soluble anion is $\mathrm{Cl}^{-}$at $1414.41 \mathrm{cmole}^{-1}$ $1^{-1}$ followed by $\mathrm{SO}_{4}{ }^{2-}$ at $1193.90 \mathrm{cmole}^{-1}$, whereas the $\mathrm{HCO}_{3}{ }^{-}$is below one cmole ${ }^{-1}$. The average $\mathrm{EMgP}$ stands at 48.85 compared with ESP at 31.75 . This is confirmative evidence indicating seawater intrusion. Given these provisions, it is concluded that soil reclamation in the investigated localities for crop cultivation is dubious. An aquaculture production system may turn out to be a sagely alternative scenario.
\end{abstract}

Key words: Sinai, El-Tina plain, salinity, allocative efficiency.

\section{INTRODUCTION}

Overpopulation, demographic imbalance, urbanization, employment, and desertification are some of the intricate problems that Egypt must solemnly consider. A common factor in the analysis of these problems is that they are related to natural resources management, especially soil and water. More than often, feasible practical solutions are compromise trade-offs solutions when it comes to sector demand/completion. The contemplated development of Sinai Peninsula offers an illustrative example.

A plethora of development plans and research work on Sinai was undertaken in the last few decades as a component of a national

\footnotetext{
*Corresponding author: Tel. : +201012185545

E-mail address: saharselim98@yahoo.com
}

agenda. In a historical perspective, the reports submitted by Dames and Moore (1985) are probably the first thrust to formulate a comprehensive regional plan. It was reiterated that industry, recreational tourism, and agriculture could serve as sound drivers for development. A few years later, Euroconsult (1992) classified the Mediterranean coast and hinterlands of Sinai into groups and units of terrestrial or aquatic environments within each group. The northwestern part of Sinai was presented as a priority area for agricultural development.

The suggested area consists of five reclamation blocks, most prominent of which is El-Tina plain covering some 50,000 faddans 
(0.42 hectare each). Irrigation water will be delivered by El-Salam/Sheikh Gaber Canal, which was subsequently designed to serve a mega soil reclamation project over a command area of 620,000 faddans east and west of Suez Canal. The water load of the canal emanates from two sources. The first is the River Nile taken from the tail of Damietta Branch before it reaches the Mediterranean Coast. The second is drainage water from El- Serw and Hadous drains before they reach the southern edge of Lake Manzala. The adopted mixing mechanism provides that salinity of the water mix does not exceed $1000 \mathrm{ppm}$, which implies that the water is not really pristine. Therefore, as described by Tahoun (2009), appropriate measures should be taken when using this water for irrigation, especially on heavy-textured soils.

Stanley and co-workers (1996, 1998, 2014), Dewidar and Frihy (2003) and Kaiser (2009) stipulated that El-Tina plain is about $818 \mathrm{~km}^{2}$ in area with a concave shoreline configuration. The plain can be divided into distinct geomorphic units including sandy shore, coastal plain, marginal lagoon, Nile flood plain, sand dune belt, and sabkhas. The area is covered with Quaternary sediments of littoral nature, alluvial and aeolian origin which show variations in texture and composition ranging from unconsolidated sands to salinized silt and clay of chemical and biochemical origin. Sneh et al. (1986), Stanley and Warne (1998), and Quintanar et al. (2013) explained the nature of clay sediments in the area. They demonstrated that there was a major Nile distributary channel by the name of Pelusiac Branch that split off from the main trunk of the Nile heading northeast to the Mediterranean Sea across the northwestern coast of Sinai. The branch used to carry considerable loads of water and sediments. Based on presumed climatic and anthropogenic reasoning, the channel was chocked by sand and silt deposits from prograding beach accretion processes, and became defunct. El Gammal (2013) argued that the area of Pelusium on the Mediterranean shoreline suffered from frequent tectonic movements the latest of which occurred in $870 \mathrm{AD}$.

As far as land use is concerned, El-Shazly and Abdel-Gaphour (1990), Abdelmalik (1999), and Nawar (2009) warned from the ravage of soil salinity in El-Tina plain, as it would be a major soil limiting factor for agricultural utilization. Salt efflorescence is common in many soils across the area in the form of thin crust and rather thick pans of about 5 centimeters. Beneath the salt crust there is a sand zone rich in diagenetic saccharoidal gypsum crystals. Thin hard bands of gypsum may also occur at different levels close to the surface. Hassan (2002) described El-Tina plain as a landscape whose parent material is a mixture of alluvium deposits, and lacustrine sand deposits, sometimes inter-mixed with aeolian deposits. The water table in some cases is very shallow. Throughout the area, drainage condition is poor to imperfect. Nawar (2009) as well as Tahoun et al. (2011) highlighted this finding, and the prevalence of salinity and sodicity in many soils of El-Tina plain.

James et al. (1982), Aragüés and Tanji (2003), Shrestha (2006), and Urdanoz and Aragüés (2011) confirmed that soil salinity, whether primary or secondary, leads eventually to soil degradation, crop failure, and in extreme cases to land abandonment. It goes without saying that detailed spatial information on soil salinity is seminal for better soil management, particularly in areas allocated to large reclamation project of the dryland. The provisions of El-Salam/ Sheikh Gaber Canal project prioritize El-Tina plain for conventional agriculture. Yet the area does not have accurate databases warranted for rational resource allocation. The problem is exacerbated by the limited water resources to be shared by competitive sectors.

In this context, the current work was undertaken with particular emphasis on localities within El-Tina plain. The guiding principles are those of Grundwald et al. (2011) and Verhoeven (2015) who call for allocative efficiency as nexus for sustainable development. The objective of this work is two-fold. The first is to establish a data set which may identify and discern chemical features of some soils in El-Tina plain. The second is to debunk some functional relations based on the interactive links between these features. Beneficiaries and target groups of this article include relevant ministries, local administrators, sophisticated farmers, and the scientific community at large. 


\section{METHODS AND PROCEDURES}

\section{Soil Sample Collections}

A reconnaissance survey of soils in El-Tina plain within northwestern Sinai was undertaken to examine the broad soil patterns, landscape features, and some of their characteristic. This was coupled with extraction of data from satellite images and Digital Elevation Model (DEM) to generate a preliminary physiographic map. The product was subsequently checked and completed through frequent field observations and description of soils on the landscape. Thereafter, a systematic scheme was developed whereby soil samples were collected from 16 sites according to morphological variations. Longitudes and latitudes were defined in the field using a Garmen Map 60 system.

The field work of this research began by excavating, morphologically describing, and sampling the sites following the guidelines of FAO (2006). In general, the area is distinguished by flat to slightly sloping surface, which may reach $5 \%$ in places. There is no evidence for severe erosion caused by either water or wind in the area. The Soil Taxonomy System (Soil Survey Staff, 2014) was consulted. Soil morphology, total salinity, clay content, and effective soil depth were used to define diagnostic soil features. Collected soil samples were air dried, crushed, and sieved through a 2 $\mathrm{mm}$ sieve, and then stored till needed for further work. Standard analytical procedures as given by Klute (1986) and Page et al. (1982) were used as standard procedures.

\section{Physical Analysis}

Particle size analysis was determined by the pipette method. Coarse sand was separated by sieving, after removing cementing agents and deflocculating aggregates. Determination of fine sand, and silt fractions was undertaken by sedimentation from aqueous suspensions. The clay fraction was determined by evaporating aliquot of clay suspensions devoid of sand and silt after elapsed time in accordance with Stokes law.

\section{Chemical Analysis}

Soil organic matter was determined by the Walkely Black method. Calcium carbonate was determined by the calcimeter. Gypsum was determined by the dilution differential method. Values of the soil $\mathrm{pH}, \mathrm{EC}$, and soluble ions were obtained from equilibrated soil saturated extract; $\mathrm{Na}^{+}$and $\mathrm{K}^{+}$by a flame photometer; $\mathrm{Ca}^{2+}$ and $\mathrm{Mg}^{2+}$ by the versenate method, $\mathrm{Cl}^{-}$by titration with $\mathrm{AgNO}_{3} ; \mathrm{CO}_{3}^{2-}$ and $\mathrm{HCO}_{3}^{-}$by titration with an acid. Sodium adsorption ratio (SAR) was calculated from corresponding concentration of $\mathrm{Na}, \mathrm{Ca}$, and $\mathrm{Mg}$ cations in the saturated soil extract using the standard equation. Exchangeable cations were determined by displacement with ammonium acetate, and CEC by computation as sum of exchangeable $\mathrm{Na}, \mathrm{K}, \mathrm{Ca}$, and $\mathrm{Mg}$.

\section{RESULTS AND DISCUSSION}

\section{Site Description}

For the sake of avoiding unnecessary repetition under this heading, it may be reported that field inspection on a major scale of the investigated soils revealed some common features as well as specific features. Soils of all sites are barren land with no traces of vegetation. The soil depth is very shallow and the whole area shows very poor drainage conditions. The topography is flat to almost flat. Most soils seemed wet especially in the early hours of the day.

Sites localities 25, 26, 27, 30, and 31 were covered with salt crust varying in thickness from 2 to $9 \mathrm{~cm}$; sites 22, 23, 24, 28, 29, 32, 33, 34, 35, 36 , and 37 have no salt crust. With the possible exception of sites 25,26 , and 27 whose water table stands at $10 \mathrm{~cm}$ below surface, the other sites have their water table at approximately 25 $\mathrm{cm}$ below. The specific site features may be outlined as follows:

\section{Site 22}

Location: $32^{\circ} 24^{\prime} 58^{\prime \prime} \mathrm{E}, 31^{\circ} 04^{\prime} 26^{\prime \prime} \mathrm{N}$; black (7.5YR 1.7/1, moist), grayish yellow brown (10YR 5/2, dry); clay; strong medium to coarse subangular blocky structure; hard, firm, very sticky, very plastic; weak effervescence with $\mathrm{HCl}$; few dispersed gypsum crystals; common medium salt crystals.

\section{Site 23}

Location: $32^{\circ} 24^{\prime} 16^{\prime \prime} \mathrm{E}, 31^{\circ} 04^{\prime} 35^{\prime \prime} \mathrm{N}$; black (7.5YR 2/1, moist), grayish yellow brown (10YR 6/2, dry); clay loam; moderate medium 
subangular blocky structure; moderately sticky, moderately plastic; weak effervescence with $\mathrm{HCl}$; few very fine gypsum crystals; few fine salt crystals.

\section{Site 24}

Location: $32^{\circ} \quad 23^{\prime} \quad 27^{\prime \prime} \quad \mathrm{E}, \quad 31^{\circ} \quad 04^{\prime} \quad 25^{\prime \prime} \mathrm{N}$; brownish black (7.5YR 3/1, moist), grayish brown (10YR 5/2, dry); clay; moderate medium to coarse subangular blocky structure; sticky, plastic; weak effervescence with $\mathrm{HCl}$; common fine irregular gypsum concretions; common medium gypsum crystals; common medium salt crystals.

\section{Site 25}

Location: $32^{\circ} 22^{\prime} 39^{\prime \prime} \mathrm{E}, 31^{\circ} 04^{\prime} 26^{\prime \prime} \mathrm{N}$; black (7.5YR 1.7/1, moist), dull yellowish brown (10YR 5/3, dry); loam; weak fine subangular blocky structure; slightly sticky, slightly plastic; weak effervescence with $\mathrm{HCl}$; few very fine gypsum crystals; common medium salt crystals.

\section{Site 26}

Location: $32^{\circ} 22^{\prime} 37^{\prime \prime} \mathrm{E}, 31^{\circ} 04^{\prime} 36^{\prime \prime} \mathrm{N}$; black (7.5YR 2/1, moist), dull yellowish brown (10YR $5 / 3$, dry); loam; weak fine subangular blocky structure; slightly sticky, slightly plastic; weak effervescence with $\mathrm{HCl}$; few medium gypsum concretions; common fine salt crystals.

\section{Site 27}

Location: $32^{\circ} 22^{\prime} 04^{\prime \prime} \mathrm{E}, 31^{\circ} 04^{\prime} 27^{\prime \prime} \mathrm{N}$; brownish gray $(7.5 \mathrm{YR} 4 / 1$, moist), grayish yellow brown (10YR 6/2, dry); clay; strong medium to coarse subangular blocky structure; hard, firm, sticky, plastic; moderate effervescence with $\mathrm{HCl}$; few fine gypsum crystals; common fine salt crystals.

\section{Site 28}

Location: $32^{\circ} 21^{\prime} 13^{\prime \prime} \mathrm{E}, 31^{\circ} 04^{\prime} 32^{\prime \prime} \mathrm{N}$; brown (7.5YR 4/3, moist), grayish yellow brown (10YR 6/2, dry); clay; moderate medium to coarse subangular blocky structure; hard, firm, very sticky, very plastic; moderate effervescence with $\mathrm{HCl}$; very few very fine lime concretions; very few very fine gypsum crystals; few fine salt crystals.

\section{Site 29}

Location: $32^{\circ} 20^{\prime} 32^{\prime \prime} \mathrm{E}, \quad 31^{\circ} 04^{\prime} \quad 46^{\prime \prime} \mathrm{N}$; brownish black (10YR 3/1, moist), grayish yellow brown (10YR 5/2, dry); loam; weak fine subangular blocky structure; slightly sticky, slightly plastic; few gray mottles; weak effervescence with $\mathrm{HCl}$; common fine gypsum crystals; common fine salt crystals.

\section{Site 30}

Location: $32^{\circ} 20^{\prime} 32^{\prime \prime} \mathrm{E}, 31^{\circ} 05^{\prime} 05^{\prime \prime} \mathrm{N}$; black (7.5YR 2/1, moist), black (7.5YR 2/1, dry), dull yellowish brown (10YR 4/3, dry); clay; moderate medium to coarse subangular blocky structure; hard, firm, very sticky, very plastic; weak effervescence with $\mathrm{HCl}$; common medium gypsum crystals; common fine salt crystals..

\section{Site 31}

Location: $32^{\circ} 20^{\prime} 25^{\prime \prime} \mathrm{E}, 31^{\circ} 05^{\prime} 27^{\prime \prime} \mathrm{N}$; black (7.5YR 2/1, moist), dull yellowish brown (10YR $4 / 3$, dry); clay; moderate medium to coarse subangular blocky structure; sticky, plastic; moderate effervescence with $\mathrm{HCl}$; common fine gypsum concretions; common medium salt crystals.

\section{Site 32}

Location: $32^{\circ} 20^{\prime} 13^{\prime \prime} \mathrm{E}, 31^{\circ} 06^{\prime} 18^{\prime \prime} \mathrm{N}$; black (7.5YR 1.7/1, moist), grayish yellow brown (10YR 4/2, dry); clay; moderate medium to coarse subangular blocky structure; sticky, plastic; moderate effervescence with $\mathrm{HCl}$; very few medium gypsum concretions; common medium salt crystals.

\section{Site 33}

Location: $32^{\circ} 19^{\prime} 01^{\prime \prime} \mathrm{E}, 31^{\circ} 06^{\prime} 20^{\prime \prime} \mathrm{N}$; black (7.5YR 2/1, moist), grayish yellow brown (10YR 4/3, dry); clay; moderate, medium to coarse subangular blocky structure; sticky, plastic; weak effervescence with $\mathrm{HCl}$; common fine gypsum crystals; common fine salt crystals.

\section{Site 34}

Location: $32^{\circ} 20^{\prime} 36^{\prime \prime} \mathrm{E}, 31^{\circ} 07^{\prime} 29^{\prime \prime} \mathrm{N}$; black (7.5YR 2/1, moist), grayish yellow brown (10YR 4/2, dry); clay; strong medium to coarse subangular blocky structure; hard, firm, very sticky, very plastic; weak effervescence with $\mathrm{HCl}$; common very fine gypsum crystals; common fine salt crystals..

\section{Site 35}

Location: $32^{\circ} 21^{\prime} 09^{\prime \prime} \mathrm{E}, 31^{\circ} 08^{\prime} 12^{\prime \prime} \mathrm{N}$; brownish black (7.5YR 3/1, moist), dull yellow orange (10YR 6/3, dry); clay loam; moderate 
medium subangular blocky structure; sticky, plastic; weak effervescence with $\mathrm{HCl}$; few very fine gypsum crystals; common fine salt crystals.

\section{Site 36}

Location: $32^{\circ} 22^{\prime} 17^{\prime \prime} \mathrm{E}, 31^{\circ} 07^{\prime} 57^{\prime \prime} \mathrm{N}$; black (7.5YR 1.7/1, moist), grayish yellow brown (10YR 5/2, dry); clay loam; moderate medium subangular blocky structure; sticky, plastic; weak effervescence with $\mathrm{HCl}$; common very fine gypsum crystals; common fine salt crystals.

\section{Site 37}

Location: $32^{\circ} 20^{\prime} 37^{\prime \prime} \mathrm{E}, 31^{\circ} 01^{\prime} 18^{\prime \prime} \mathrm{N}$; brownish black (5YR 2/1, moist), grayish yellow brown (10YR 4/2, dry); silty clay; moderate medium subangular blocky structure; sticky, plastic; weak effervescence with $\mathrm{HCl}$; common fine gypsum crystals; common medium salt crystals.

Reassessing site inspection on a closer scale reveals some relevant facts. First, the soil structure is often well-preserved in a subangular form, and the clayey soils show considerable plasticity. Second, in most cases soil color tended to have a tint of brown/yellow component, indicating the absence of a reducing environment. Only the soil of site 29 showed conspicuous mottling. The particular reason for this unique case is a matter of speculation. Third, most soils are salt infested where the occurrence salt crystals were evident. In this context, the calcium carbonate content of the soils is low, and only the soil of site 28 showed lime concretions. Furthermore, gypsum is often present in detectable amounts either as individual crystals or as concretions.

\section{General Soil Properties}

The complete sets of field, laboratory, and analytical results of the investigated soils are reported in the Ph.D. dissertation of Shahin (2016) which is the basic reference of this paper. Table 1 presents analytical results concordant with the objectives of this paper. Table 2 shows the results of applied multivariable correlation analysis to investigate degree of similarities and the probable interrelations among parameters. The premise is that soil quality deterioration could be detected by means of such interrelations, which may also serve as indicators of cause and effect relationships.

The average soil clay content of the sampled soil population is $51.4 \%$. Nevertheless, the amplitude of variation is very large ranging between a minimum of $15.5 \%$ and a maximum of $79.4 \%$. Table 2 for correlation analysis between the investigated parameters, reveals a very high negative correlation between the soils clay and silt contents. Such result sounds reasonable, since the soil contents of these two soil separates, along with sand are complementary; the increase of a given component would necessitate a proportional decrease in the other two components. Fig. 1-a graphically illustrates this relation. An unusual feature in the figure is the presence of a gap in the clay content parameter to present a divide separating the soil population into two discontinuous groups. The first group has a clay content ranging between 15.5 and $41.0 \%$, whereas the second group ranges between 66.5 and $79.4 \%$. Equating this divide into a geographic field positioning does not yield distinct implication. Therefore, it is more than likely that the initial clay deposition in the area was affected by environmental particularities at the time.

The divide exists also when plotting the soil CEC as a function of soil clay content which is given in Fig. 1 b. The highly significant correlation between the two parameters is indicative of the meager soil organic content, which is shown for the corresponding analysis in Table 1. It is rather interesting to observe that these clay contents are considerably greater than that reported by Radwan (2008) for soils in the northernmost extremities of Kafr El-Sheikh and El-Behaira governorates. Such elevated clay content in some El-Tina soils of northwestern Sinai does not withstand two logical expectations. First, the soil parent material in the three localities is admittedly the same, belonging to the Nile alluvium. Second, the ambient sedimentation landscape of the three localities is seemingly the same, being almost flat allowing the river to dispose of its load of fine particles (El Gammal, 2013; Sestini, 1989, 1992; Sneh et al., 1986; Stanley and Clemente, 2014). 

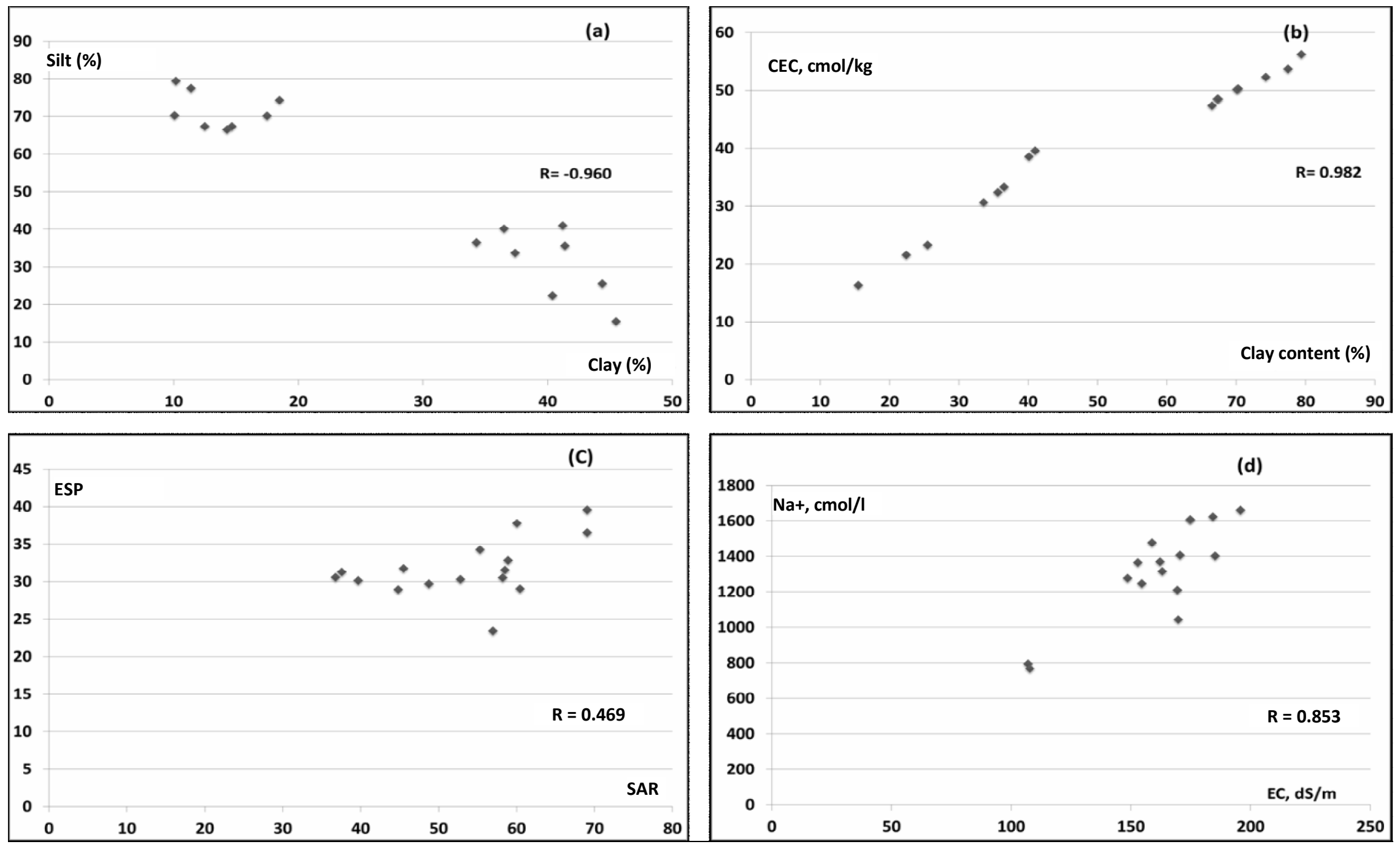

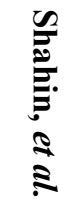

Fig. 1. Statistical relations between some soil parameters 
Table 1. Some physical and chemical analytical data of the studied soils

\begin{tabular}{|c|c|c|c|c|c|c|c|c|c|c|c|c|c|c|}
\hline \multirow{2}{*}{$\begin{array}{l}\text { Sample } \\
\text { No. }\end{array}$} & \multirow{2}{*}{$\begin{array}{l}\text { Silt } \\
(\%)\end{array}$} & \multirow{2}{*}{$\begin{array}{l}\text { Clay } \\
(\%)\end{array}$} & \multirow{2}{*}{$\begin{array}{c}\mathrm{CaCO}_{3} \\
(\%)\end{array}$} & \multirow{2}{*}{$\begin{array}{c}\text { Gypsum } \\
(\%)\end{array}$} & \multirow{2}{*}{$\begin{array}{l}\text { OM } \\
(\%)\end{array}$} & \multirow[t]{2}{*}{$\mathrm{pH}_{\mathrm{e}}$} & \multirow{2}{*}{$\begin{array}{c}\mathrm{EC}_{\mathrm{e}} \\
\mathrm{dS} \mathrm{m}^{-1}\end{array}$} & \multicolumn{4}{|c|}{ Soluble cations, $\mathrm{cmol} \mathrm{I}^{-1}$} & \multicolumn{3}{|c|}{ Soluble anions, $\mathrm{cmol} \mathrm{I}^{-1}$} \\
\hline & & & & & & & & $\mathrm{Na}^{+}$ & $\overline{\mathbf{K}^{+}}$ & $\mathrm{Ca}^{2+}$ & $\mathbf{M g}^{2+}$ & $\mathrm{Cl}^{-}$ & $\mathrm{HCO}_{3}{ }^{-}$ & $\mathrm{SO}_{4}{ }^{2--}$ \\
\hline$\overline{22}$ & 10.2 & 79.4 & 2.6 & 4.74 & 0.84 & 7.8 & 195.9 & 1660.14 & 58.70 & 477.17 & 1110.40 & 1754.05 & 0.84 & 1551.52 \\
\hline 23 & 37.4 & 33.6 & 1.2 & 4.86 & 0.91 & 7.4 & 107.1 & 792.99 & 35.01 & 214.20 & 584.45 & 887.01 & 1.00 & 738.64 \\
\hline 24 & 12.5 & 67.3 & 1.4 & 5.23 & 0.98 & 7.7 & 163.2 & 1315.91 & 52.05 & 343.30 & 897.23 & 1322.30 & 0.96 & 1285.23 \\
\hline 25 & 44.4 & 25.5 & 2.4 & 4.38 & 1.05 & 7.5 & 162.2 & 1368.9 & 68.15 & 268.13 & 887.11 & 1510.24 & 1.05 & 1081.00 \\
\hline 26 & 40.4 & 22.4 & 2.5 & 4.98 & 1.00 & 7.5 & 153.0 & 1365.61 & 62.40 & 334.40 & 686.43 & 1464.06 & 0.61 & 984.17 \\
\hline 27 & 18.5 & 74.3 & 3.1 & 5.23 & 1.05 & 7.6 & 169.4 & 1209.74 & 53.90 & 406.50 & 1050.03 & 1405.21 & 0.64 & 1314.32 \\
\hline 28 & 17.5 & 70.1 & 3.2 & 4.78 & 1.05 & 7.5 & 107.9 & 767.40 & 41.60 & 322.05 & 511.15 & 901.41 & 0.98 & 739.81 \\
\hline 29 & 45.5 & 15.5 & 1.3 & 5.11 & 0.98 & 7.5 & 169.8 & 1044.14 & 47.50 & 501.12 & 1110.20 & 1215.12 & 0.64 & 1487.20 \\
\hline 30 & 10.1 & 70.3 & 1.6 & 5.34 & 1.16 & 7.8 & 170.5 & 1407.04 & 88.90 & 438.10 & 856.20 & 1584.13 & 0.94 & 1205.17 \\
\hline 31 & 14.7 & 67.4 & 3.6 & 5.32 & 0.96 & 7.5 & 184.3 & 1622.56 & 45.40 & 409.03 & 1050.13 & 1656.41 & 0.96 & 1469.75 \\
\hline 32 & 36.5 & 40.1 & 3.4 & 4.68 & 1.05 & 7.6 & 185.2 & 1401.93 & 33.12 & 608.60 & 1286.67 & 1710.32 & 1.05 & 1618.95 \\
\hline 33 & 14.3 & 66.5 & 1.2 & 5.06 & 1.23 & 8.3 & 174.9 & 1607.83 & 91.00 & 377.32 & 705.14 & 1610.43 & 0.83 & 1170.03 \\
\hline 34 & 11.4 & 77.5 & 1.4 & 4.91 & 1.00 & 7.6 & 158.9 & 1478.04 & 41.60 & 476.23 & 811.56 & 1394.02 & 0.64 & 1412.77 \\
\hline 35 & 34.3 & 36.5 & 1.2 & 4.77 & 0.94 & 7.7 & 154.7 & 1246.36 & 51.50 & 323.09 & 984.21 & 1309.21 & 0.86 & 1295.09 \\
\hline 36 & 41.4 & 35.6 & 1.1 & 4.86 & 1.05 & 7.7 & 148.7 & 1277.16 & 63.80 & 306.41 & 645.32 & 1296.24 & 0.96 & 995.49 \\
\hline 37 & 41.2 & 41.0 & 1.2 & 5.06 & 1.23 & 8.3 & 174.9 & 1607.83 & 91.00 & 377.32 & 705.14 & 1610.43 & 0.83 & 742.18 \\
\hline Average & 26.9 & 51.4 & 2.1 & 5.0 & 1.03 & 7.7 & 161.3 & 1323.34 & 57.85 & 386.44 & 867.59 & 1414.41 & 0.86 & 1193.20 \\
\hline Median & 26.4 & 53.8 & 1.5 & 5.0 & 1.03 & 7.6 & 166.3 & 1367.25 & 52.98 & 377.32 & 871.66 & 1434.63 & 0.90 & 1245.63 \\
\hline Max. & 45.5 & 79.4 & 3.6 & 5.3 & 1.23 & 8.3 & 195.9 & 1660.14 & 91.00 & 608.60 & 1286.67 & 1754.05 & 1.05 & 1618.95 \\
\hline Min. & 10.1 & 15.5 & 1.1 & 4.4 & 0.84 & 7.4 & 107.1 & 767.40 & 33.12 & 214.20 & 511.15 & 887.01 & 0.61 & 738.64 \\
\hline Range & 35.4 & 63.9 & 2.5 & 1.0 & 0.39 & 0.9 & 88.8 & 892.74 & 57.88 & 394.40 & 775.52 & 867.04 & 0.44 & 880.93 \\
\hline
\end{tabular}


Table 1. Cont.

\begin{tabular}{|c|c|c|c|c|c|c|c|c|}
\hline \multirow{2}{*}{$\begin{array}{l}\text { Sample } \\
\text { No. }\end{array}$} & \multicolumn{4}{|c|}{ Exchangeable cations, $\mathrm{cmol} \mathrm{kg}^{-1}$} & \multirow[t]{2}{*}{ CEC, $\mathrm{cmol} \mathrm{kg}^{-1}$} & \multirow[t]{2}{*}{ SAR } & \multirow[t]{2}{*}{ ESP } & \multirow[t]{2}{*}{ EMgP } \\
\hline & $\mathrm{Na}^{+}$ & $\mathbf{K}^{+}$ & $\mathrm{Ca}^{2+}$ & $\mathrm{Mg}^{2+}$ & & & & \\
\hline 22 & 18.44 & 2.64 & 6.56 & 28.56 & 56.21 & 58.92 & 32.81 & 50.82 \\
\hline 23 & 9.22 & 1.11 & 5.43 & 14.84 & 30.61 & 39.68 & 30.13 & 48.50 \\
\hline 24 & 14.68 & 1.43 & 5.98 & 26.41 & 48.51 & 52.84 & 30.27 & 54.45 \\
\hline 25 & 5.46 & 1.31 & 4.99 & 11.54 & 23.31 & 56.96 & 23.43 & 49.53 \\
\hline 26 & 6.24 & 1.44 & 4.65 & 9.17 & 21.48 & 60.45 & 29.02 & 42.65 \\
\hline 28 & 15.66 & 1.35 & 6.54 & 26.55 & 50.09 & 37.60 & 31.26 & 52.99 \\
\hline 29 & 4.98 & 0.67 & 4.22 & 6.43 & 16.27 & 36.79 & 30.55 & 39.45 \\
\hline 30 & 17.22 & 1.54 & 6.22 & 25.32 & 50.31 & 55.31 & 34.23 & 50.34 \\
\hline 31 & 18.31 & 1.45 & 6.41 & 22.33 & 48.51 & 60.07 & 37.75 & 46.04 \\
\hline 32 & 12.23 & 1.41 & 5.88 & 18.98 & 38.51 & 45.54 & 31.77 & 49.30 \\
\hline 33 & 18.71 & 1.32 & 6.14 & 21.13 & 47.32 & 69.11 & 39.56 & 44.67 \\
\hline 34 & 16.37 & 1.89 & 6.22 & 29.22 & 53.71 & 58.25 & 30.48 & 54.41 \\
\hline 36 & 10.22 & 1.43 & 5.54 & 15.21 & 32.42 & 58.55 & 31.54 & 46.94 \\
\hline 37 & 14.47 & 1.24 & 5.66 & 18.23 & 39.59 & 69.11 & 36.54 & 46.04 \\
\hline Average & 12.95 & 1.47 & 5.75 & 19.98 & 40.15 & 53.30 & 31.75 & 48.85 \\
\hline Median & 14.58 & 1.43 & 5.93 & 20.06 & 43.45 & 56.14 & 30.91 & 49.34 \\
\hline Мax. & 18.71 & 2.64 & 6.56 & 29.32 & 56.201 & 69.11 & 39.56 & 56.06 \\
\hline Min. & 4.98 & 0.67 & 4.22 & 6.43 & 16.27 & 36.79 & 23.43 & 39.45 \\
\hline Range & 13.73 & 1.97 & 2.34 & 22.89 & 39.90 & 32.32 & 16.13 & 16.61 \\
\hline
\end{tabular}


This incompatible result may be interpreted based on a discussion elaborated by Stanley and Warne (1998) on the old Nile Delta. They estimated that since seven millennia down to the nineteenth century, 5 to $10 \times 10^{6}$ tonnes of Nile alluvium sediments were deposited per annum in the delta proper. They added that the sediments were carried along seven Nile channels. These include the Pelusiac Branch pointing to the northeast to reach northwestern Sinai, the Sebennitic Branch to the north crossing what is now Kafr El-Sheikh Governorate, and the Canopic Branch to the northwest crossing what is now El-Behaira Governorate. There is evidence to indicate that sediments reaching the coast were reworked by marine processing in a general eastward direction along the coast. Marine waves molded the coastline so that the delta margin configuration began to resemble the modern arcuate shoreline. Therefore, it is most likely that the clay content of soils of El-Tina plain in northwestern Sinai might have been replenished by this marine processing.

One more feature of the soil clay content needs to be highlighted. It is the high correlation coefficients between, not only the CEC values, but also between the magnitudes of each of the individual exchangeable cations. But things do not seem to be that simple. When correlating clay with the saturation percentages of cations, $\mathrm{EMgP}$ shows significant correlation, whereas ESP fails to show significance. Further work is invited to solve the incompatibility.

The $\mathrm{CaCO}_{3}$ of invariably all soils is rather small, far less than the calcareous limit; providing support to the site inspection section of this work. There is justification to believe that this phase belongs to diagenetic process. Interestingly, Table 2 does not show any significant correlation between this component and any of the determined and computed parameters. Given the elaboration of Babel and Schreiber (2014) on the genesis of calcite in soils and sediments, it may be hypothized that calcite in the studied soils was formed via the reaction:

$\mathrm{Ca}^{2+}{ }_{(\mathrm{aq})}+2 \mathrm{HCO}_{3_{(\mathrm{aq})}^{-}} \rightarrow \mathrm{CaCO}_{3(\mathrm{~s})}+\mathrm{H}_{2} \mathrm{O}_{(\mathrm{l})}+\mathrm{CO}_{2(\mathrm{~g})}$

Where (aq) is aqueous or soluble in water, (s) is solid, (l) is liquid, and (g) is gas.
Expectantly, calcite precipitation would diminish the concentration of bicarbonate in the system, as substantiated by the results of Table 1 .

The case of gypsum occurrence in the investigated soils is inviting for discussion. First, it is to be noted that the gypsum content is greater than that of calcium carbonate, $5.0 \% \mathrm{vs}$ $2.1 \%$. Such presence is expected given the proximity of the area to the Mediterranean coast, promoting seawater intrusion followed by water evaporation and the subsequent separation of a series of evaporites.

When seawater intrudes open land, exposure to atmospheric conditions stimulates vaporization, which induces solution concentration, and the beginning of sequential evaporites separation. Hassan (2002), Tahoun et al. (2011), and Nawar (2009) reported the presence of gypsum in many soils of northern Sinai. Pedogenic horizons of gypsum containing fairly large crystals were detected by Abdel-Aal (1971) in the soils of ElSerw locality in the northern extremities of the Delta. He interpreted such presence in terms of the influence of shallow groundwater and the parent material as well as topography.

Gomis-Yagues et al. (2000), Boluda-Botella et al. (2004), and Babel and Schreiber (2014) added that gypsum crystallization begins when vaporization reduces the solution to a ratio $\mathrm{V}_{\mathrm{er}}=$ 0.2 . The first gypsum crystal usually is finegrained. In more concentrated solutions, it appears as firm coarser-crystalline crusts commonly displaying the centimeter-todecimeter large domal structures. The presence of a complex, living microbial community, particularly cyanobacteria, within gypsum sediments profoundly influences the geochemical micro environment, leading to increased photosynthetically produced oxygen up to concentration equal four times air saturation during the day, but that oxygen remains within the interstitial brine. The relevance of such processes to the fact that gypsum was present either as discrete crystals or concretions need further investigations.

The $\mathrm{pH}$ values of Table 1 show limited variation between soils. There is a case where the values are consistently high, reaching 8.3, particularly in site 33 . In contrast, there are cases 
Table 2. Correlation analysis ( $r$ ) of multivariate studied soil parameters

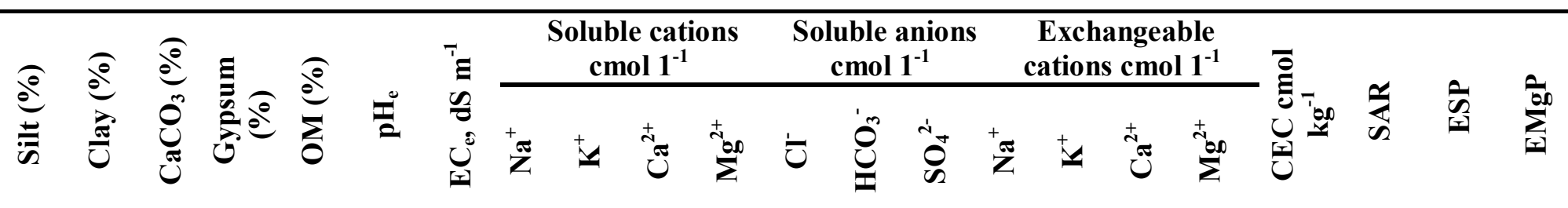

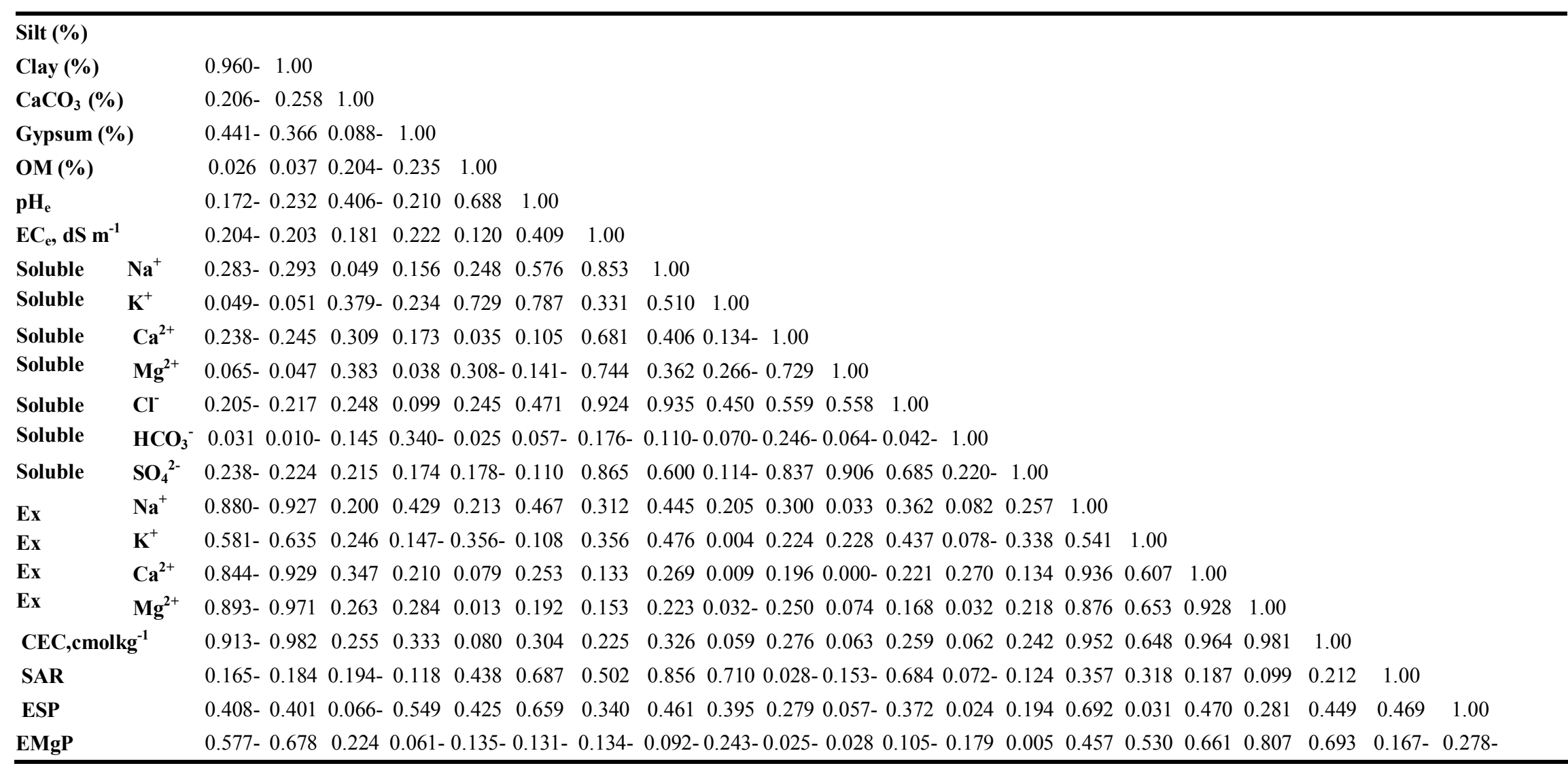


where the $\mathrm{pH}$ values are comparatively modest at 7.5. This case is represented by sites 25,26 , 39 and 31 .

Prevalence of soil salinity in all tested samples is shown by the extremely high electrical conductivity of their saturated extract, reaching $195.9 \mathrm{dS} \mathrm{m}^{-1}$. Such values were expected given encountered salt crystals in the field inspection. In association with salinity, soil sodicity expressed either by ESP or SAR is excessively high. The electrical conductivity is correlated with the concentration of ions in the soil extract except $\mathrm{K}^{+}$from the cationic suite and $\mathrm{HCO}_{3}{ }^{-}$from the anionic suite. The lack of such correlation in these two particular ions might be interpreted by their deflated low concentration. Sodium ion concentration is very highly correlated with the $\mathrm{Cl}^{-}$with a correlation coefficient of 0.935 whereas its correlation coefficient with $\mathrm{SO}_{4}{ }^{2-}$ is modest at 0.600 . Whether or not the $\mathrm{SO}_{4}{ }^{2-}$ was depleted by the reaction with $\mathrm{Ca}^{2+}$ is an entertained possibility to be explored in further work. This line of argument is the apparent strong correlation between the concentration of both $\mathrm{Ca}^{2+}$ and $\mathrm{SO}_{4}{ }^{2-}$ at 0.837 whereas its correlation with $\mathrm{Cl}^{-}$is minor at 0.559 .

The dominant soluble cation is $\mathrm{Na}^{+}$with an average of $1323.34 \mathrm{cmole}^{-1}$ followed by $\mathrm{Mg}^{2+}$ at $867.59 \mathrm{cmole}^{-1}, \mathrm{Ca}^{2+}$ at $386.44 \mathrm{cmole}^{-1}$, and $\mathrm{K}$ at $57.85 \mathrm{cmole}^{-1}$. The dominant soluble anion is $\mathrm{Cl}^{-}$with an average concentration of $1414.41 \mathrm{cmole}^{-1}$ followed by $\mathrm{SO}_{4}{ }^{2-}$ at 1193.20 cmole $1^{-1}$, whereas the $\mathrm{HCO}_{3}^{-}$concentration is negligible, falling below one cmole $1^{-1}$. As given in Table 2 and Fig. 1 (d) for $\mathrm{Na}^{+}$as a model, most of the soluble soil components are positively correlated with the EC.

Suarez (1981), James et al. (1982) and more recently Pils et al. (2007) and Bourrie (2014) advanced that SAR determined in saturated soil extract may be used as a substitute for the determination of the ESP. The substitution is based on two tacit assumptions. First, $\mathrm{Ca}$ and $\mathrm{Mg}$ ions have equal selectivity for exchange, and second, the exchange phase composition is fixed by the total concentrations of the exchangeable ions rather than their activities. Tahoun and coworkers $(1995,1999,2011)$ substantiated experimentally this concordant relation in certain soils, but also reported discordant exceptions. It was found that the relation holds for soils with low salinity, but goes astray for soils with high salinity. Figure 1-c shows the relation for the latter case pertinent to soils of this work as an example.

The work of Pils et al. (2007) and Bourrie (2014) may be utilized to interpret the inconsistency. A multifaceted argument goes as follows. First, cations in soil solution have different threshold concentration, which is defined as the value of the concentration of electrolyte that results in a $10-15 \%$ decrease from its initial value during dilution. The threshold concentration for $\mathrm{Mg}^{2+}$ saturated clays is three times larger than that for $\mathrm{Ca}^{2+}$ saturated clays. Such difference is ascribed to greater hydration energy of $\mathrm{Mg}^{2+}$ as compared to $\mathrm{Ca}^{2+}$. Second, the displacement of exchangeable $\mathrm{Ca}^{2+}$ by $\mathrm{Na}^{+}$and the reverse, shows demixing and quasi-crystals (QCs) breakup and formation. In low ionic strengths systems, demixing with monovalent cations on the external surfaces and divalent cations on the internal surfaces of QCs largely controls the average size of QCs in suspensions. In high ionic strength systems, both monovalent and divalent cations are found in the interlayers. The average size of QCs is controlled by the monovalent to divalent cation ratio, the hydration energies of the cations, and the ionic strength of the system. This is to say in a simple manner that with soils of excessive salinity, it seems that the chemical microenvironment of the soil system is perturbed to nullify the supposedly concordant relation between SAR and ESP.

It is most interesting to note that values of exchangeable $\mathrm{Mg}$ content given in Table 1 is far greater than the exchangeable $\mathrm{Na}$ counterpart in every and each soil. The average content in the soil community is $19.98 \mathrm{cmole} \mathrm{kg}^{-1}$ for $\mathrm{Mg}$ in contrast with $12.95 \mathrm{cmole} \mathrm{kg}^{-1}$ for $\mathrm{Na}$. The corresponding values of $\mathrm{EMgP}$ and $\mathrm{ESP}$ carry the same trend. The average EMgP value stands at 48.85 compared with ESP value at 31.75 . Values of soluble cations in conjunction with their exchangeable values bring two sets of complications. First, the overall average soluble $\mathrm{Na}$ at $1323.34 \mathrm{cmole}^{-1}$ is far dominant surpassing $\mathrm{Mg}$ at $867.59 \mathrm{cmole}^{-1}$ by a factor of about 2 , yet the overall average of exchangeable $\mathrm{Mg}$ is 19.98 cmole $\mathrm{kg}^{-1}$ exceeds the $\mathrm{Na}$ at $12.95 \mathrm{cmole} \mathrm{kg}^{-1}$ by a factor of about 1.6. 
In this connection, it is interesting to refer to the findings of Sayles and Mangelsdorf Jr. (1977). They investigated the equilibration of clay immersed in seawater for periods up to150 days. It was found that $\mathrm{Mg}^{2+}$ moved into the exchange positions in preference to $\mathrm{Ca}^{2+}$ and $\mathrm{Na}^{+}$. Kaolinite adjusted very rapidly, but montmorillonite and mixed layer minerals were slow to reach equilibrium. In the process, reacting minerals released appreciable amounts of $\mathrm{SiO}_{2}, \mathrm{Al}_{2} \mathrm{O}_{3}$, and $\mathrm{Fe}_{2} \mathrm{O}_{3}$ in the order: montmorillonite $>$ illite $>$ kaolinite $>$ halloysite. Furthermore, Pils et al. (2007) investigated the effect of demixing on the breakup and formation of smectite quasicrystals (QCs). They indicated that a Ca-dominated system enhances both the formation of large QCs and flocculation. In contrast, increasing $\mathrm{Na}^{+}$concentration induces the breakup of large Ca-QCs and dispersion. As large $\mathrm{Ca}-\mathrm{QCs}$ breakup, monovalent cations reside primarily on the external surfaces whereas $\mathrm{Ca}^{2+}$ is preferentially retained in the interlayers.

\section{General Discussion and Conclusions}

The on-farm Egyptian experience in the reclamation of salt-infested soils, particularly in the northern extremities of the Nile Delta, is not only extensive, but also well-documented. However, when it comes to soils of El-Tina plain, the paucity of data is embarrassingly too little. The authors were able to encounter a single publication written by Abdel-Dayem et al. (2000), which deserves to be revisited.

They implemented a prototype of field trials to reclaim salt-infested soils in El-Tina plain using the prescribed conventional wisdom. Soil profiles in the area are deep, and the clay content in most cases ranges around 40\%. A mimic local drain was excavated around the locality, and then individual soil reclamation processes took precedence. Such processes involved land leveling, mechanically removing salt crusts, and establishing field irrigation and drainage networks as starters. Subsequently, gypsum was applied followed by lavish soil leaching. Brackish water was used for the initial leaching stages then fresh water followed, either intermittently or continuously. After 3 long years, a considerable proportion of salinity and sodicity was removed to create an enabling environment for a viable agriculture.
The feasibility of replicating the prototype of Abdel-Dayem et al. (2000) to localities investigated in this work is most likely dubious. The submitted justifications are numerous. First, the considered soils have very shallow soil depth due to elevated water table reaching $10 \mathrm{~cm}$ below surface in places. Second, the clay content of some soils is extremely high approaching $80 \%$. Third, the salinity and sodicity loads are overwhelming. Fourth and most important of all, is the undeniable need of mega volumes of water for leaching, in a time of extremely scarce water resources. In the circumstances, allocative efficiency as nexus for sustainable development as set by Grundwald et al. (2011) and Verhoeven (2015) would be grossly thwarted.

Therefore, the possibility of using soils in certain localities in El-Tina plain for crop cultivation is assuredly not recommended. In retrospect, allocating such land to establish an aquaculture production system may turn out to be a sagely resource allocation.

\section{REFERENCES}

Abdelmalik, K.W.M. (1999). Integrated geoenvironmental assessment of development activities in North Western Sinai, Egypt. Ph.D. Thesis. Geol. Dept., Fac. Sci., Ain Shams Univ., Egypt.

Abdel-Aal, R.M. (1971). Effect of ground water and parent material on different soil characteristics in the Northeast Nile Delta. Ph. D. Thesis, Fac. Agric., Cairo Univ., Egypt.

Abdel-Dayem, S., D. W. Rycroft, F. Ramadan and A. Tahoun (2000). Reclamation of saline clay soils in the Tina plain, Egypt. ICID, 49: 17-28.

Aragues, R. and K.K. Tanji (2003). Water quality of irrigation return flows. In B.A. Stewart and T.A. Howell (Ed.) Encyclopaedia of Water Sci. Marcel Dekker, New York, 502-506

Babel, M. and B. C. Schreiber (2014). Geochemistry of evaporites and evolution of seawater. Pp 484-560 in Treatise on Geochemistry, $2^{\text {nd }}$ Ed. H. Holland and K. Turekian (eds.). Elsevier, the Netherland. 
http://dx.doi.org/10.1016/B978-0-08-0959757.00718-X

Boluda-Botella, N., V. Gomis-Yagües, F. RuizBeviá, and M. D. Saquete-Ferrándiz (2004). Gypsum precipitation/dissolution during seawater intrusion. Pp 511-519 in the $18^{\text {th }}$ Salt Water Intrusion Meeting (SWIM), Cartagena, Spain. L. Araguás, E. Custodio and M. Manzano (eds.).

Bourrie, G. (2014). Swelling clays and saltaffected soils: demixing of $\mathrm{Na} / \mathrm{Ca}$ clays as the rationale for discouraging the use of sodium adsorption ratio (SAR). Eurasian Soil Sci., 3: 245 - 253

Dames, S. and A. Moore (1985). Sinai Development Study, Phase I: Draft Final Report. Cent. Int. Develop. and Technol., California.

Dewidar, Kh.M. and O.E. Frihy (2003). Thematic mapper analysis to identify geomorphologic and sediment texture of ElTina plain, north-western coast of Sinai, Egypt. Int. J. Remote Sen., 24: 2377-2385.

El Gammal, S.A. (2013). Implication of Holocene catastrophic tectonic activities on archaeological sites at Mediterranean shore north west Sinai Egypt. Austr. J. Basic, and Appl. Sci., 7: 221-234.

El-Shazly, M.M. and E.S.A. Abdel-Gaphour (1990). Genesis, formation and classification of soils of the coastal plain of the Sinai peninsula. Egypt. J. Soil Sc., 30: 59-72.

Euroconsult, W. (1992). Northwestern Sinai Agriculture Development Project. In association with Pacer and Darwish Engineers. World Bank/ Arab Republic of Egypt. Environ. Impact Ass., 1, Main Rep.

FAO (2006). Guidelines for land use planning. FAO development series 1. Food and Agriculture Organization of the United Nations, Rome, Italy.

Gomis-Yagues, V., N. Boluda-Botella and F. Ruiz-Bevi (2000). Gypsum precipitation/ dissolution as an explanation of the decrease of sulphate concentration during seawater intrusion. J. Hydrol., 228: 48-55.

Grundwald, S., J.A. Thompson and J.L. Boettinger (2011). Digital soil mapping and modeling at continental scales: finding solutions for global issues. Soil Sci. Soc. Am. J., 75: 1201-1213

Hassan, M.A.A. (2002). Environmental studies on coastal zone soils of the North Sinai peninsula (Egypt) using remote sensing techniques. Manuskript, zu finden in www. fal.de. Aus dem Institut für Pflanzenernährung und Bodenkunde. Landbauforschung Völkenrode Sonderheft 238. Braunschweig, Bundesforschung sanstalt für Landwirtschaft (FAL).

James, D.W., R.J. Hanks and J. Jurinak (1982). Modern Irrigated Soils. John Wiley, New York.

Kaiser, M.F. (2009). Environmental changes, remote sensing, and infrastructure development: The case of Egypts East Port Said harbor. Appl. Geography, 280-288.

Klute, A. (1986). Methods of Soil Analysis: Part 1 Physical and Mineralogical Methods, $2^{\text {nd }}$ Ed. Soil Sci. Soc. Am. Madison, WI, USA.

Nawar, S. (2009). Mapping units of some soil of El-Salam canal basin using geographic in formation systems (GIS). M. Sc. Thesis, Fac. Agric., Suez Canal Univ., Ismailia, Egypt.

Page, A.L., R.H. Miller and Keeney (1982). Methods of Soil Analysis Part-2. Chemical and Microbiological Properties, $2^{\text {nd }}$ Ed. Soil Sci. Soc. Am. Madison, WI., USA.

Pils, J.R.V., D.A. Laird and P.V. Evangelou (2007). Role of cation demixing and quasicrystal formation and breakup on the stability of smectitic colloids. Appl. Clay Sci., 35: 201-211.

Quintanar, J., S.D. Khana, M.S. Fathy and A.A. Zalat (2013). Remote sensing, planform, and facies analysis of the Plain of Tina, Egypt for the remains of the defunct Pelusiac River. Sedimentary Geol., 297: 16-30.

Radwan, A.A. (2008). Indicators of soil degradation in arid regions. $\mathrm{Ph}$. D. Thesis. Fac. Agric., El-Zagazig Univ., Egypt.

Sayles, F.L. and P.C. Mangelsdorf Jr. (1977). The equilibration of clay minerals with sea water: exchange reactions. Geochimica et Cosmochimica Acta 41: 951-960. 
Sestini, G. (1989). Nile Delta: a review of depositional environments and geological history. Geological Soc., London, Special Publications 41, 99-127.

Sestini, G. (1992). Implications of climatic changes for the Nile delta. In: L Jeftic, J. D. Milliman, and G. Sestini (eds.), Climatic Change and the Mediterranean. Edward Arnold, London

Shahin, S.A. (2016). Spatial decision support system for land use management in Port Said area Egypt. Ph.D. Thesis, Fac. Agric., Zagazig Univ., Egypt.

Shrestha, R.P. (2006). Relating soil electrical conductivity to remote sensing and other soil properties for assessing soil salinity in northeast Thailand. Land Degrad. Dev., 17: 677-689.

Sneh, A., T. Weissbrod, A. Ehrlich, A. Horowitz, S. Moshkovitz and A. Rosenfeld (1986). Holocene evolution of the northeastern corner of the Nile Delta. Quaternary Res., 26: 194- 206.

Soil Survey Staff (2014). Key to Soil Taxonomy. A Basic System of Soil Classification for Making and Interpreting Soil Surveys. $2^{\text {nd }}$ Ed., Agriculture Hand Book No. 436, USDA, Washington DC.

Stanley, D.J. (1996). Nile Delta: extreme case of sediment entrapment on a delta plain and consequent coastal land loss. Marine Geol., 129, 189-195.

Stanley, D.J. and A.G. Warne (1998). Nile Delta in its destruction phase. J. Coastal Res., 14: 794-825.
Stanley, J.D. and P.L. Clemente (2014). Clay distributions, grain sizes, sediment thicknesses, and compaction rates to interpret subsidence in Egypt's northern Nile Delta. J. Coastal Res., 30: 88-101.

Suarez, D.L. (1981). Relation between pHc and sodium adsorption ratio (SAR) and an alternative method of estimating SAR of soil or drainage waters. Soil Sci. Soc. Am. J., 45: 469-475.

Tahoun, S.A. (2009). Environmental Perspectives of the Port Said Area. Center of GIS for Studies and Serv., Zagazig Univ., Egypt.

Tahoun, S. A., A. A. Sheha, S. M. Dahduoh, and M. A. Hassan (1995). Potassium status in soils of El-Sharkia Governorate, Egyption. J. Soil Sci., 35: 163 - 175.

Tahoun, S.A., I.A. El-Garhi, I.R. Mohamed and A.H. El-Falah (1999). Assessment of some micronutrients in the soils of Abu-Hammad, Egypt. J. Soil Sci., 39: 383-396.

Tahoun, S.A., S.A. Hassanein and S.A. Radwan (2011). Native and loaded heavy metals in soils of the Port Said area, Egypt. Egypt. J. Soil Sci., 51: 223-237.

Urdanoz, V. and R. Aragues (2011). Pre- and post-irrigation mapping of soil salinity with electromagnetic induction techniques and relationships with drainage water salinity. Soil Sci. Soc. Am. J., 75: 207-213.

Verhoeven, H. (2015). The nexus as a political commodity: agricultural development, water policy and elite rivalry in Egypt. Int. J. Water Resour. Develop., 31: 360-374. 
الســــمات الكيمـــاوية لبعضض مـــوارد الأراضــ في ســــل الطينة شـــمال غرب سيناء ـــصر

سحر عبدالله سليم السيد شاهين 1 ـ صلاح أحمد طاحون2 ـ ثروت كامل غبور 1 ـ السيد أحمد حسن الناقة2

$$
\begin{aligned}
& \text { 1. قسم الأراضي واستغلال المياه ـ المركز القومي للبحوث ـ القاهرة ـ مصر لهر }
\end{aligned}
$$

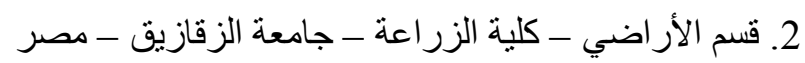

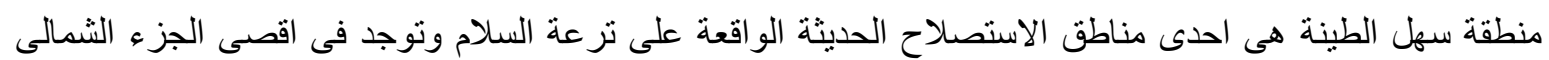

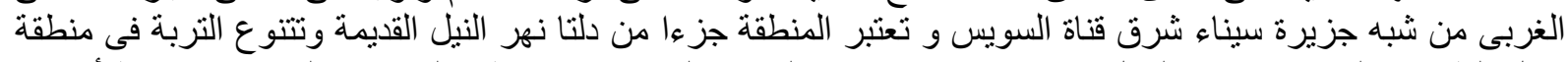

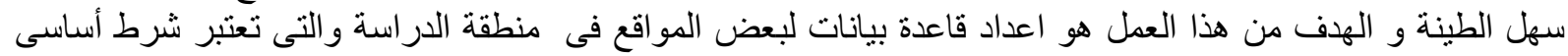

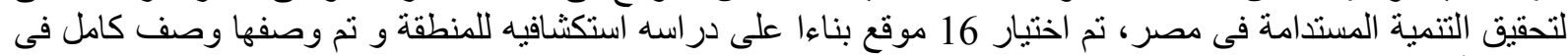

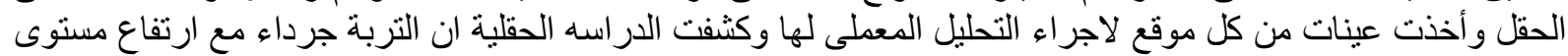

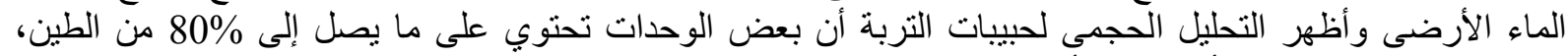

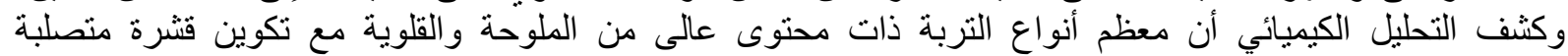

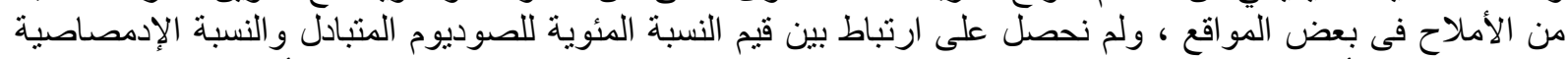

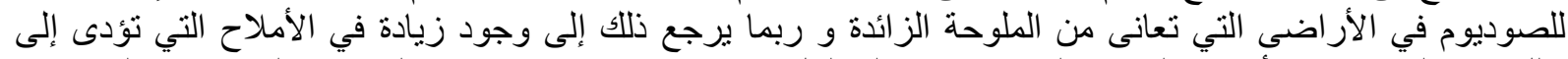

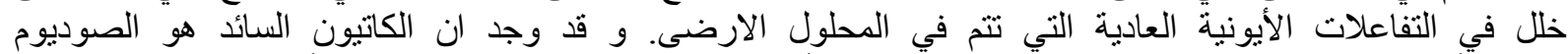

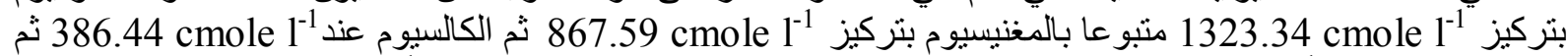

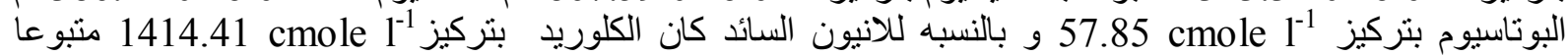

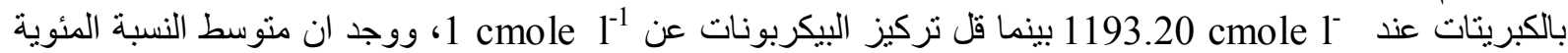

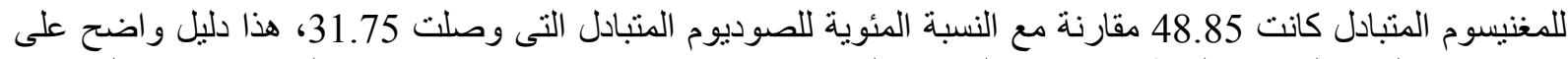

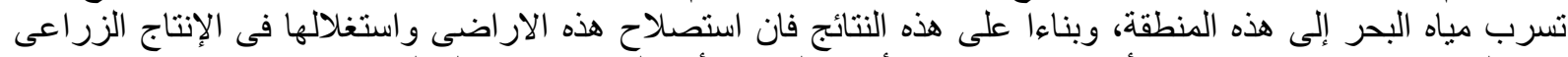
مشكوك فيه ويمكن استخدام هذه الأر اضى في إنتاج الأحياء المائية كأحد السيناريو هات النيات البديلة .

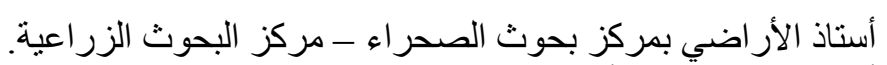
أستاذ ورئيس قَّم الأر اضي - كلية الزر اعة الهر - جامعة الزقازيق. 